\title{
The Condition of Media Education in Slovak Schools
}

\author{
Viera Kačinová / Viktória Norisová / Norbert Vrabec* \\ Faculty of Mass Media Communication \\ University of Sts. Cyril and Methodius \\ Trnava, Slovakia \\ viera.kacinova@ucm.sk \\ viktoria.norisova@ucm.sk \\ norbert.vrabec@ucm.sk \\ *Corresponding author
}

\begin{abstract}
This paper aims at identifying the condition of media education in Slovak schools by means of quantitative research methods. The authors present the results of a representative research carried out by IMEC - International Media Literacy Centre at the Faculty of Mass Media Communication at the University of Sts. Cyril and Methodius in Slovakia. The research was aimed at mapping the current situation of media education in the content of education at Slovak primary and secondary schools, identifying the predominant form of education and assessing the competence of media education teachers. The research data is based on a quantitative analysis of 22 case studies of practical media education examples.
\end{abstract}

Keywords- Media Education; State Curriculum; Teacher'S Training; Project Teaching.

\section{INTRODUCTION}

The role of school-based media education is to provide individuals with the ability to adapt to the reality of life surrounded by media and, at the same time, to teach them to adapt media reality to their own needs. "Media itself has become an integral part of the culture of modern society." [1] The essential aspect of a school-based media education content is to define the competences of the participants of the education process in the context of taking their specific social role. From the point of view of personal traits to be developed by means of the individual's contact with media, it is important to form a sensible and responsible media user who can critically assess media content and use it selectively, especially with regard to its quality (the existence of universal values) and its positive contribution to their own personality. Schools are emphasized by education experts as platforms for enhancing critical thinking towards the increasing influx of new information. In general, the stimulation of positive values and elimination of negative ones is of social interest. [2] "Media education is therefore a focused and planned interactive teaching and learning about media with a view to fostering the ability of an individual to selectively, sensibly and thus critically and responsibly (in accordance with a positive personal contribution) perceive and use media. “ [3]

The school content reform which took place in Slovakia between 2008 and 2009 put an obligation on primary and secondary schools to include media education into their curricula. When discussing the media's effect and its influence on people, children and youngsters are considered to be an at- risk group. [4] Media education was taught at Slovak schools in the past, but until 2011 there was a lack of complex mapping and analysis involving all degrees of education. The research led by IMEC - International Media Literacy Centre at the Faculty of Mass Media Communication at the University of Sts. Cyril and Methodius in Trnava between 2011 and 2012 was aimed at identifying the current state of the implementation of the topic into the curricula at primary and secondary schools in Slovakia.

\section{METHODOLOGY}

The following points were defined as research objectives: (1) to define the scale of media education's presence in the content of education at primary and secondary schools (comparison of all Slovak regions according to the individual school types); (2) to find the predominant media education form used at primary and secondary schools in the individual regions of Slovakia according to the individual school types (e.g. as an individual subject, as part of other subjects, an individual project, a course, etc.); (3) to define the level of education (qualification) of media education teachers at primary and secondary schools in Slovakia.

The following methods were combined as the research methodology: the questionnaire method as the main research method (a questionnaire was distributed to schools via e-mail); a content analysis of school and national curricula available on schools' web sites; a phone interview (with headmasters, deputy headmasters or media education teachers), in selected cases, a personal standardized interview was carried out with a representative of the school management or a media education teacher directly at school. The representative research sample consisted of 567 primary schools and 631 grammar schools and secondary vocational schools from all Slovak regions. Primary schools, grammar schools with a 4-year, 8-year and combined study period, secondary vocational schools and conservatories, public, religious, private, urban and rural schools were represented.

\section{RESUlts}

\section{A. The scope of presence of media education in schools}

The results of the research published in the final reports showed that media education is taught at 430 primary schools, which represents $76 \%$ of all schools involved in the research. 
In the questionnaire survey and the analysis of basic pedagogic documents, it was discovered that at 137 schools, which constitutes $24 \%$ of the schools involved, media education is not taught at all.

Further results showed that out of the total of 461 public schools, media education is taught at 345 schools (75\%) and at 116 schools $(25 \%)$ it is not taught at all. Out of 75 religious schools involved in our sample, $58(77 \%)$ provide media education, whereas 17 (23\%) do not. 27 (87\%) schools out of the total of 31 private schools teach media education and 4 schools $(13 \%)$ do not. The results also showed that media education is taught at 361 secondary schools in Slovakia, which represents $57 \%$, whereas, at 270 schools, i.e. $43 \%$ of the schools involved in the research, media education is not taught at all.

Out of 205 participating grammar schools, media education is taught at $159(78 \%)$, whereas at $46(22 \%)$ it is not. Out of 415 secondary vocational schools, $199(48 \%)$ provide media education, $216(52 \%)$ do not. The largest presence of media education was identified at religious secondary schools. From the total of 61 schools, $46(75 \%)$ stated that they taught media education and $15(25 \%)$ schools did not. The poorest presence of media education was found at private secondary schools. Out of 107 schools involved in the research, 58 (54\%) do not teach media education, whereas only 49 (46\%) do. Out of 463 public secondary schools, $266(57 \%)$ provide media education and 197 (43\%) do not.

\section{B. The form of media education in schools}

One of the objectives of the research was to determine the predominant form of media education at primary and secondary schools. "Media education is, in the international scientific community, considered to be one of the most effective means to acquire key competencies necessary for an interactive and inclusive use of media and critical perception of a constantly growing spectrum of media messages." [5] Media education in Slovakia is defined as a so-called cross-sectional topic in the state curricula, which represent binding legal guidelines concerning education for schools. In accordance with their characteristics, cross-sectional topics may be implemented at schools as: (1) an integrated part of the content of education and suitable subjects, (2) a separate subject belonging to additional classes (in accordance with the school's profile), (3) a project or a course. The character of a cross-sectional topic primarily implies its inclusion in other areas of education. According to the state curricula, cross-sectional topics usually coincide with various education areas and thus their content is implemented into selected subjects. [6] At the same time, it is possible for schools to make use of free classes and to create media education as a separate subject in their own school curricula. According to previous findings, [7] Slovak schools tend to teach media education as a separate subject, however, it was never analysed to what extent and whether there are differences in the form of education between individual types of schools. The research findings proved that the predominant form of media education at Slovak schools is its integration into different areas of education. Media education is integrated into other subjects at $40 \%$ of all primary schools. At $10 \%$ of Slovak primary schools, media education represents a separate subject or an interest group; the project form is used by $29 \%$ of schools, whereas $21 \%$ of primary schools opted for other forms, e.g. a discussion with a journalist at school, students' visits and tours of media, film screenings followed by a discussion, and many others. At several schools, integrated and separate education forms, as well as various separate forms, are used simultaneously.

The project form of education proved to be the most popular one. Out of all primary schools involved, 255 stated that they made use of this form in media education. 215 schools claimed to run a school magazine, 53 schools run a television channel or a radio station, 56 schools use their websites as a tool in media education. 26 schools opted for the "others" category and provided examples of e.g. a project of cooperation with the national daily SME in analysing newspaper articles, Looking for Role Models project, final projects focusing on media at the end of each school year, etc. It was also revealed that religious primary schools organize separate media education subjects on a larger scale when compared to other types of schools. Furthermore, the results of the research showed that primary schools largely integrate media education into the following subjects or areas of education: Slovak Language and Literature (259 schools), Information Technology (179 schools), Civic Education (140 schools), Ethics (131 schools) and Arts and Culture, including the subjects of Music Education, Arts Education and Aesthetic Education (123 schools). Biology, foreign language classes, History, class meetings and Religious Education were mentioned by the school representatives among other subjects.

The questionnaire was also aimed at identifying the topics concerning media education taught within relevant subjects. The fact that very few schools provided information on specific topics represented a problem in the analysis. Furthermore, the analysis revealed that many of the topics were connected to media didactics rather than media education. In media didactics, media is used as a tool for education, i.e. visual tools or tools used for explaining a topic belonging to a different subject in order to achieve various education objectives. Relevant topics were stated in the following subjects:

- Slovak Language and Literature - reading comprehension, television and radio genres, media and identity, media products

- Arts and Culture - practical work with media, advertisements - production, advertisement ethics, perception of art, emotions in art.

- Ethics - values, media ethics.

- Information Technology - practical skills, safe use of the Internet.

- History - historical development of media.

- Civic Education - free time and media, educational programmes for children and youngsters.

- Religious Education - values in media.

- Foreign language classes - how media influences us, how media works. 
- Class meetings - discussing topics from the Children and Web publication, protecting pupils from the negative impact of ICT and mass media, positives and negatives of media.

Similarly to primary schools, secondary schools involved in the research (more precisely $54 \%$ of them) include media education in other subjects. Secondary schools integrate media education predominantly into the following subjects or education areas: Slovak Language and Literature (156 schools), Civic Education (153 schools), Ethics (121 schools), Arts and Culture (103 schools). 10\% of secondary schools provide a separate subject or interest group for media education (compulsory or compulsory-optional), $22 \%$ organize a media education project (including activities such as a school magazine, a school web site, etc.). Other forms, e.g. a discussion with a journalist at school, students' visits and tours of media, film screening followed by a discussion etc. were chosen by $14 \%$ of the schools. Furthermore, the research has shown that schools usually opt for teaching media education as a combination of several forms.

\section{Competence of media education teachers}

"Europe and Slovakia have clearly demonstrated the need to integrate media education in the formal education system. They have also placed emphasis on the importance of fostering critical thinking by means of media education." [8] The main indicator directly connected to the quality of media education in schools is the teachers' competence. Most teachers who were respondents of our research claimed that they did not feel sufficiently prepared to teach media education and they were aware of the need for further education and methodological support in this area (by means of methodological materials aimed at media education). [9] An integral part of the research was therefore connected to the media education competence of teachers at Slovak schools. The teachers were evaluated as competent if they had completed at least one of the following forms of education: (1) an accredited form of education, (2) teacher's training, (3) a short-term form of education. Only a small percentage of primary and secondary schools claimed that their teachers had completed any of the media education forms.

Only 7\% (39 schools) among primary schools involved in the research claimed to have provided such education for their teachers. $3 \%$ ( 20 schools) have chosen an accredited form of education, $3 \%$ ( 15 schools) a short-term form of education and $1 \%$ (4 schools) a training session. 93\% (528) of the schools surveyed currently do not employ a teacher who has completed any of the forms of media education. 10\% (60 schools) of the secondary schools claimed that their teachers have gone through one of the forms of education. 29 schools (5\%) have chosen an accredited form of education and 24 schools (4\%) a short-term education, whereas 7 schools (1\%) have chosen a training form. Only a small number of schools have specified the scale of the education form or the institution providing the education.

\section{DISCUSSION}

The research findings have shown that although primary and secondary schools in Slovakia are obliged by the valid binding pedagogic legislation to include media education into their curricula, they apply it in an insufficient manner. There are a number of schools which claim that they do not teach media education and the number could be even higher if teachers do not understand the content of the topic (media as a subject for education) and confuse it with media didactics (where media is merely a tool for education). This is partially demonstrated by the presented research findings. A certain level of formal approach to education might arise from the inclusion of media education as a cross-sectional topic into the national curricula.

The high percentage of secondary vocational schools where media education is not taught at all is a result of its definition and placement in the national curricula, which define the obligatory content of education for individual groups of subjects. In the compulsory part of education, media education is not stressed directly (it is not defined as a cross-sectional topic in contrast with grammar schools), it is only partially included in other compulsory areas of education or key competences - mainly as a part of the competence of being a democratic citizen, etc. In practice, secondary vocational schools include media education similarly to grammar schools, in the context of creating a school profile or completing the content of education in school curricula. According to our findings, the schools rely on the binding pedagogic legislation for grammar schools education and, at the same time, react to the current social need to integrate media education into the content of education.

The research has also shown that the integrated form is the predominant form of media education and has a high interest for schools in the project form of education as detected. It is clear that the use of school projects is not perceived as merely an alternative approach. This was proven by the quantitative analysis of good practice examples of media education at primary and secondary schools gathered during the competition organized by IMEC from June 2014 to October 2014. The aim of the competition was to gather good educational practice examples aimed at fostering the media literacy of Slovak pupils and provide them to teachers in a teacher's handbook. During the analysis of 22 case studies, it was shown that the project form was applied as an education method in 18 cases. In 11 cases media education was integrated into the scope of other subjects, mainly Slovak Language and Literature, Information Technology, Arts and Culture. In 10 cases, media education was a separate subject. It was confirmed that schools predominantly organize media education as a combination of several forms.

The research has shown an insufficient level of teacher's competence in media education, resulting from the lack of education opportunities for teachers. A qualified teacher is the key pillar of successful media education in schools. The virtual world created by multimedia shapes a new generation of tools that can be used for the development of education. [10] Training sessions for teachers who are able to teach media education are currently organized mainly by means of a more or less continuous professional development. However, it is necessary to increase the offer of quality training for teachers in the system of their continuous development. Short-term and continuous forms of education should be aimed at expanding 
the professional knowledge and didactic competence of teachers to teach media education according to one of the forms of media education at schools. Educational institutions providing training courses for teachers should organize educational programs for teachers tailored to the specific requirements and needs of schools. From the point of view of the effectiveness of media education at schools, it is necessary to ensure their formation on a larger scale and with erudition in their gradual training.

Universities should play a more active role in the education of teachers, tutors and professionals of media education who are able to find their place in the formal education system, as well as the informal education system or in media. Media education should be included in study programs of university studies on a larger scale than have been until now. It has been a part of study plans only as a compulsory-optional subject mainly as part of mass media communication studies and occasionally of pedagogic study programs also. The only university currently offering a university study program in this area is the Faculty of Mass Media Communication at the University of Sts. Cyril and Methodius in Trnava as a part of the accredited study programs of Applied Media Studies for the bachelor's, master's and doctorate degrees. Graduates of the Applied Media Studies program apply their knowledge mainly in the process of production and distribution of print, audio, audio-visual and digital mass media content with a special focus on the area of education, as well as in the production of programs aimed at media education. By studying complementary pedagogic studies, graduates can obtain the pedagogic competence to teach media education at primary and secondary schools. However, in the future, media education should be included at universities in pedagogic programs at faculties of education, arts and other faculties which directly shape future primary and secondary school teachers.

The unsatisfactory results of media education inclusion is partially caused by weak promotion of media education as an educational topic for the content of education, which also leads to insufficient interest by teachers in the topic. In this case, it is necessary to create a system of advice in media education, which is non-existent at the moment. A greater motivation to teach media education at schools could also be promoted by means of well-prepared didactic materials on media education, which are currently scarce in Slovakia.

\section{ACKNOWLEDGEMENT}

This contribution was supported by the Slovak Research and Development Agency under Contract No. APVV-0754-12.

\section{REFERENCES}

[1] J. Matúš, "Media and culture," in European Journal of Science and Theology, vol. 10, suppl. 1, 2014, p. 93.

[2] L. Volko, "National and global aspects in the context of media" in Marketing identity: design that sells, J. Matúš, D. Petranová, Trnava: University of Ss. Cyril and Methodius in Trnava, Faculty of Mass Media Communication, 2013, p. 259.

[3] V. Kačinová, "Terminologické problémy mediálnej výchovy," in Communication Today, vol. 3, n. 2, 2012, p. 29.

[4] D. Petranová, L. Burianová, "Importance and role of new media in the process of media literacy education, “ in Psychology and psychiatry, sociology and healthcare, education: sociology and healthcare: conference proceedings, volume II., Sofia: STEF92 Technology, 2014, p. 389 .

[5] N. Vrabec, "New approaches to research and evaluation of key competencies related to media literacy," in Psychology and psychiatry, sociology and healthcare, education: sociology and healthcare: conference proceedings, volume II., Sofia : STEF92 Technology, 2014, p. 551 .

[6] Electronic Publication: “Štátny vzdelávací program. Mediálna výchova ako prierezová téma: Príloha ISCED 2,“ Bratislava, Štátny pedagogický ústav. 2008, p. 21.

[7] V. Kačinová, "Ako d’alej s mediálnou výchovou v slovenskom školstve?" in Mediálna výchova v otvorenom priestore: zborník príspevkov z konferencie 20. ročníka Ceny Dunaja. Bratislava: Exproduction, 2010, pp. $42-43$.

[8] D. Petranová, "Does media education at schools develop students' critical competences?" in Communication Today, vol. 2, n. 1, 2011, p. 73.

[9] L. Bekéniová, “Aktuálny stav implementácie mediálnej výchovy do edukácie v SJaL v ZŠ," in Pedagogické rozhl'ady, vol. 20, n.1, 2011, pp. 3-5.

[10] M. Solík, J. Lalúhová, J. Višňovský, "Media as a tool for fostering values in the contemporary society" in European Journal of Science and Theology, vol. 9, n. 6, 2013, p. 77. 